\title{
Constructing Constructivism in Management Accounting \\ Education: Reflections from a Teaching Cycle with Innovative Learning Elements
}

\begin{tabular}{|r|l|}
\hline Journal: & Qualitative Research in Accounting and Management \\
\hline Manuscript ID & QRAM-05-2020-0067.R2 \\
\hline Manuscript Type: & Original Article \\
\hline Keywords: & $\begin{array}{l}\text { Radical Constructivism, Deep Learning,, Qualitative Methodology, } \\
\text { Teaching Cycle, Management Accounting Education }\end{array}$ \\
\hline \multicolumn{2}{|l}{} \\
\hline
\end{tabular}

\section{SCHOLARONE \\ Manuscripts}


Constructing Constructivism in Management Accounting Education: Reflections from a Teaching Cycle with Innovative Learning Elements

\begin{abstract}
Purpose:

The study addresses the possibility of integrating some elements of the 'radical constructivist' approach to management accounting teaching. It answers the following two questions: to what extent should management accounting educators construct a 'radical constructivist' foundation to guide active learning? and in which ways can management accounting educators use qualitative methods to facilitate 'radical constructivist' education?
\end{abstract}

\title{
Methodology:
}

The study uses a teaching cycle that implements innovative learning elements, e.g. learning from ordinary people, designed following the principles of 'radical constructivism', to engage students with 'externalities' at the center of their knowledge construction. It adopts an ethnographic approach comprising interviews and participant observation for the data collection, followed by the application of qualitative content and narrative analysis of the data.

\section{Findings:}

The study findings and reflections illustrate that the majority of students respond positively to radical constructivist learning if the educators can develop an innovative problem-solving and authentic environment that is close to their real lives. The radical constructivist teaching cycle discussed in this study has challenged the mind-sets of the management accounting students since it altered the traditional objectivist academic learning approaches that students were familiar with. Its use of qualitative methods facilitated active learning. Student feedback was sought as part of the qualitative design, which provided a constructive mechanism for the students and educators to learn and unlearn from their mistakes. This process enriched the understanding of learners (students) as well as educators of successful engagement in radical constructivist management accounting education and provides a base upon which to design future teaching cycles.

\section{Originality:}

The paper provides proof of the ability of accounting educators, as change-agents, to apply radical constructivist epistemology combined with multiple qualitative research methods by creating new constructive learning structures and cultures associated with innovative deeplearning tasks in management accounting education. 
Keywords: Radical Constructivism, Deep Learning, Qualitative Methodology, Teaching Cycle, Management Accounting Education.

\section{Introduction}

Drawing on conversations in constructivist learning theory (Vygotsky 1978; Hardy \& Taylor, 1997; Gash, Steffe \& Thompson, 2000; 2014; Riegler \& Steffe, 2014; Ancelin-Bourguigon, 2019; Jacobson et al., 2019; Jack \& Saulpic, 2019), this paper aims to address the possibility of integrating some elements of the 'radical constructivist' approach into the teaching of management accounting (von Glaserfeld, 1974, Vygotsky, 1978; von Glaserfeld, 1989). The idea that teachers as change-agents bring their epistemological instances, from the perspective of social or pragmatic constructivist learning, into the class room with their research-lead teaching and qualitative approaches is not new in accounting education and research (Jack \& Saulpic, 2019). Since the 1970s, many educators and cognitive psychologists have proposed constructivism as an alternative epistemology within which to develop an 'approach' made up of motivation and strategy in higher education institutions (Tonge \& Willett, 2012; Turner \& Baskerville, 2013; Wilkin, 2014). The argument underpinning these proposals is that this epistemology allows students to interpret and construct their own realities, based on their experiences and interactions in the particular learning environment, with support from teachers (Marton \& Saljo, 1976; Von Glasersfeld, 1995; Paisey \& Paisey, 2005; Boyce et al., 2012; Fordham, 2012; Stanley \& Marsden, 2012). Constructivist education enhances the deep learning process as it leads to a deeper understanding of the content and subject matter being studied (Turner and Baskerville, 2013).

In contrast with the traditional teacher-centred environment, in constructivist accounting education, the agency of teachers creates an epistemologically social constructivist environment through their learner- centred classrooms (Jack \& Saulpic, 2019; AncelinBourguigon, 2019). Supporting this social constructivist view in accounting education, Boyce et al. (2012) raise the issue that new university accounting subjects require a reflexive case study approach that incorporates social and critical perspectives. They argue that such an approach has the ability to integrate humanistic and formative education and deep and elaborative learning. Similarly, Paisey \& Paisey (2005), Doran et al. (2011), Tonge \& Willett (2012) and Wilkin (2014) advocate the use of more action research and research-led problem-based learning tasks, within a constructivist learning environment, to improve the accounting curriculum. More recently, Jacobson et al. (2019) have provided empirical 
insights from a case example on how to use pragmatic constructivism, as a basis for the development of a paradigmatic foundation management accounting education.

However, this research in constructivist accounting education still focuses only on a subset of intersubjective experiences, i.e. person-to-person interaction in social constructivism, which contribute to the broader construction of knowledge. While this form of constructivism creates a very important part of accounting students' knowledge construction process, it overlooks the 'externalities' at the center of their knowledge construction. For example, as constructivist studies in mathematics education argue, "the students act as individual learners and as their own constructors of knowledge, and they think and use seemingly independent mathematical or scientific laws and theories to explicitly constructive processes that resolve cognitive perturbations aroused by a failure to attain a desired goal state of meaning making or problem solving" (Hardy \& Taylor, 1997, p. 10). From the 'radical constructivist' perspective (von Glaserfeld, 1989), the information or knowledge cannot simply pass from one person to another (e.g. the teacher to student), but the individuals construct and add new knowledge and understanding to already existing knowledge and experiences, through active learning (Von Glaserfeld, 2013).

In order to create this radical form of knowledge construction, the constructivist management accounting educators therefore, must think about innovative ways to guide their students to learn the principles of accounting, by engaging with externalities outside classroom, such as external structures and everyday life experiences. One such example involves the 'informal accountants' operating outside formal work places, e.g. home accountants, fishermen, farmers or informal business people: they all tend to use accounting principles and techniques such as oral accounting, home budgeting and relevant costing, to manage their family or informal business income and expenditure (see Gallhofer \& Chew, 2000; Jacobs \& Kent, 2002; Jacobs \& Walker, 2004; Jayasinghe \& Wickramasinghe, 2007) yet the majority have probably never learned accounting through passive objectivist teaching or training offered in a classroom environment. Instead, they have actively generated this knowledge through their life experiences and interactions with others. This paper therefore argues that in order to create such an active learning environment, qualitative research methods such as used in the ethnographic approach, need to be integrated more within management accounting teaching cycles (see Jack \& Saulpic, 2019). Addressing this gap, this paper attempts to answer the following two research questions: (i) To what extent should management accounting 
educators construct a 'radical constructivist' foundation to guide active learning? and (ii) In what ways can management accounting educators use qualitative methods such as ethnography to facilitate 'radical constructivist' education?

The paper presents a teaching cycle that incorporated innovative learning elements designed along the principles of 'radical constructivism', as an illustrative case study. Within the cycle, management accounting students engaged with 'externalities' at the center of their knowledge construction, i.e. social interactions with their family members/friends. They were also invited to reflect on their previous knowledge and life experiences with regards to facing the external structures, in order to reflect on and learn about management accounting principles. This teaching cycle, implemented in a UK university (Level 2, Management Accounting module), highlights the potential of using everyday life decision scenarios, i.e. financing and budgeting at home, to promote independent problem-based learning tasks in management accounting education. Contributing to the accounting education literature, it also showcases how qualitative methodology, in the form of an ethnographic approach that includes informal interviews, participant observation (Geertz, 1988) and narrative analysis, can be used to reflect students' perceptions and approaches to learning and their learning outcomes (Duff \& McKinstry, 2007). The underlying pedagogical rationale for this teaching cycle was to create an environment in which students could think, debate and argue actively among themselves, before acting on and mobilising their individual capacities to achieve module learning objectives.

The paper is organised and presented as follows. The first section elaborates the current state of constructivist accounting education research and practice. This is followed by a description of the case study context and information about the teaching cycle that was the focus of this study. The next section explains the research methods adopted in the study and the study design which combined explains an innovative radical constructivist case study with an ethnographic approach. The analysis of perceptions, approaches and constructivist learning outcomes from the perspective of the students' learning experiences is presented in the following section. The final two sections offer some overall reflections on the teaching cycle and concluding remarks, with a discussion of how the study's findings contribute to the knowledge and future development of management accounting education and research. 


\section{Current state of constructivist accounting education research and practice}

Since the 1970s but more especially, since the 1980, a number of accounting researchers have attempted to study accounting practices in the contexts in which they operate, using qualitative methods, and to understood accounting as both a social and an institutional practice (Paisey \& Paisey, 2005; Doran et al., 2011; Boyce et al., 2012; Tonge \& Willett, 2012; Wilkin, 2014; Ancelin-Bourguigon, 2019; Jacobson et al., 2019; Jack \& Saulpic, 2019). At the same time, accounting educators have been criticised for still emphasising information transmission through simplified teaching materials and examination questions that can be answered from lecture notes (Accounting Educational Change Commission, 1990). In response, many accounting educators have reported that their students have achieved better learning outcomes through engaging in innovative learning environments and programmes based on constructivist learning (e.g. Montano et al., 2004; Stout \& West, 2004; McPhail, 2005; English et al., 2004; Flood \& Wilson, 2008; Ballantine et al., 2008; Byrne et al., 2009; Watty et al., 2010; Doran et al., 2011; Boyce et al., 2012; Tonge \& Willett, 2012; Wilkin, 2014; Ancelin-Bourguigon, 2019; Jacobson et al., 2019; Jack \& Saulpic, 2019). Montano et al. (2004) emphasised the importance of encouraging accounting students to develop non-technical skills, and presented evidence based on using decisionoriented complex case studies in a financial statement analysis class. Stout \& West (2004) described the positive experience of managing an innovative management accounting graduate course, while McPhail (2005) discussed a community service project designed for an Accounting and Business Ethics course, aimed at encouraging students to consider the public interest.

Studies conducted by English et al. (2004), Flood \& Wilson (2008), Ballantine et al. (2008), Byrne et al. (2009) and Giraud \& Saulpic (2019) identified a positive relationship between a deep approach and qualitative differences in learning outcomes. For example, Byrne et al. (2009) carried out a comparative analysis of variations in learning approaches among firstyear students at a UK and an Irish university and reported that while both groups used more strategic approaches, the UK students seemed to apply more deep-learning approaches than the Irish students. The researchers went on to argue for the importance of including graduate capabilities/generic skills in accounting education, and that teachers should create environments that engage students deeply in group work, professional and academic writing, and the like. 
Such approaches require educators to integrate their innovative teaching cycles with a qualitative research approach (Ancelin-Bourguigon, 2019; Jacobson et al., 2019; Jack \& Saulpic, 2019). For instance, portraying educational science research and concepts, AncelinBourguigon (2019) provides evidence for the importance of integrating qualitative research into constructivist management accounting teaching. Overall, these studies suggest that the current accounting education environment does encourage learners to become involved in the active construction of knowledge, for example through case studies and action research (Duff et al., 2008; Samkin \& Francis, 2008), and to engage with the subject matter and its logical and intellectual challenges, through their own ideas and creative work (Doran et al., 2011). The teaching cycle described in the current paper was motivated and informed by these initiatives.

Taking the above discussion to an epistemological level, some researchers have tried to understand the foundations and principles behind the deep learning approach (AncelinBourguigon, 2019; Jacobson et al., 2019; Jack \& Saulpic, 2019; Jacobson et al., 2019). According to them, it follows the constructivist epistemology, which views learning as an active, constructive, intentional, complex, contextualised, reflective and collaborative exercise and encourages learners to construct meaning through relevant learning activities (Fosnet, 1996; Biggs, 2003; Chapman et al., 2005; Duff \& McKinstry, 2007; Lucas \& Mladenovic, 2009). The literature, theory and framework of approaches to learning are based on a constructivist approach and grounded in the daily world of the learner, and allow him/her to develop meaningful student-directed deep learning, and to create meaning for him/herself (Fosnot, 1996; Biggs, 2003; Duff \& McKinstry, 2007). This type of learning effectively takes place within a social or participatory environment that encourages reflective dialogue and collaboration.

Education researchers have pointed out that interactivity has a strong effect on learning and have demonstrated that people learn faster and develop stronger attitudes towards learning, when they engage in a participatory environment in which they are actively constructing knowledge (Lucas \& Mladenovic, 2009). Such students expect multiple perspectives, authentic activities and real-world cases, in order to associate with the constructivist learning environment. Particularly, Wilson \& Cole (1991) noted that the constructivist epistemology in relation to deep learning, requires educators to combine four principles so as to create a constructivist design for the teaching and learning environment: (1) the embedding of 


\section{Case Study}

\subsection{Context of the course}

The Management Accounting module that provided the context for the teaching cycle, which ran over two semesters and consisted of 36 lecture hours and 8 tutorials. The module was taught by two lecturers/educators, the author of this paper being one of them. The author of this paper was given the responsibility to manage the coursework element, since the first five lectures of the module had been taught by him. It was considered to be a core module of the year 2 programme of Accounting and Finance degree, pre-requisites being level 1 courses (first-year) Management Accounting 1 and Financial Accounting 1. Management Accounting 1 was assessed through written coursework and in addition, informal conversations with the whole class revealed that the majority of students had some part-time work experience (in various business environments), although not directly related to professional accounting. In the following year (year 3), the students would be expected to do the Advanced Management Accounting module, for which the module under study here was one of the pre-requisites. Overall, there were 60 students enrolled in the module and the coursework. According to the admission records, the students enrolled in this degree course (Accounting and Finance) had 
generally obtained a tariff score of 300 marks from their GCE (A level) exams with the volume and depth of ' $\mathrm{A}$ ' level or equivalent of 80 marks. The demographic profile of the students on the course is presented in Table 1.

The BA in Accounting and Finance was mainly taken by accounting specialists (students who aspire to have a career in accountancy). The degree scheme was accredited by the Accounting Institute's Board of Accreditation and has also attracted exemptions from the Association of Chartered Certified Accountants (ACCA). This accreditation reduces the number of subsequent examinations students need to take after graduating in order to become a qualified accountant. This has created great motivation among the students to commit themselves to the practical learning activities that take place in and outside the class.

\subsubsection{Intended learning outcomes of the module}

The main aim of the course was to help students develop the knowledge and skills required in management accounting. The course requires the students to apply the concepts, techniques and thinking from management accounting to business decision- making. The 'overall learning outcomes' of the Management Accounting module are presented in Table 2. In addition, Table 2 shows the intended 'topic learning outcomes' and their connection with the 'overall learning outcomes' of the Module (also their connections with the SOLO taxonomy). Accordingly, the coursework tasks that were designed for the module assessment were mainly aimed to achieve the 'topic learning outcomes' and by doing so creating the ground for achieving 'some parts' of overall learning outcomes of the module (1-3). However, it was not the aim of this coursework to make the students achieve entire learning outcomes of the management accounting module. In terms of transferable skills, the aim of the planned assessment tasks (30\%) was to give students the opportunity to analyse data, apply judgment, solve problems and communicate effectively in writing through clear and concise wordprocessed essays. In contrast, the final examination of the module $(70 \%)$ targeted technical proficiency in the major areas of management accounting, with questions aimed at testing self-assessment and application skills. The final exam was also supposed to determine whether the students could translate the learning gained through other assessment tasks into a "management accounting" context. 


\subsubsection{Assessment tasks, and teaching and learning activities of the module}

The module assessment consisted of two parts: 70\% was allocated to a two-hour examination and $30 \%$ was allocated to one piece of coursework (both in Semester 2). The previous year's academic session of the module expected to educate the students about the role and applications of management accounting techniques in formal business organisations. Its course work design (30\%) anticipated the students to provide answers to a written case study question involving some practical accounting issues and problems in a given decision-making scenario of a formal business organisation, e.g. preparing a Balanced Scorecard (BSC) for an Airline company and providing advice on some managerial decision making.

Responding proactively as the change-agents of the management accounting teaching group, two educators involved with this module agreed to make two changes to the module's design and delivery compared to the previous academic session, in an attempt to promote students' critical analysis and evaluation abilities. Firstly, the module scope was expanded from typical organisational-level accounting to the societal level, with the intention of demonstrating how accounting is embedded in all social actions and, in particular, how accounting concepts and decision models are used by ordinary people with or without any previous knowledge (e.g. home accounting). The objective was to introduce management accounting as a broader phenomenon rather than just a technical and private-sector-oriented practice. Secondly, appropriate outside the class-room case study activities were included in the coursework/assessment, requiring students to analyse and evaluate certain decision scenarios from everyday life, e.g. buying a family house, using management accounting concepts. The objective of this format was to motivate students to develop a deeper understanding of the application of management accounting techniques and to appreciate their limitations and behavioural aspects, through critical analysis and evaluation. This teaching and learning methodology was entirely based on the principles of radical constructivist epistemology with a deep-learning approach (Bruner, 1986; Fosnot, 1996; Biggs, 2003; von Glaserfeld, 1989; Hardy \& Taylor, 1997; von Glaserfeld, 2013). However, the purpose of this change in the current year was not to make the entire course embedded into this constructivist philosophy. Since this year's coursework ( $30 \%$ of total marks) is expected to provide an initial experience for much bigger changes in coming years, the main course was blended with both objectivist and constructivist teachings and assessment procedures (see Ancelin-Bourguignon, 2019). The SOLO taxonomy method (Biggs and Collis, 1982; Biggs and Tang, 2007) allowed the researcher to focus the management accounting class and add layers to the students' learning. 
The levels of thinking and learning that make up the SOLO taxonomy and the learning tasks in the management accounting coursework, are presented in Table 3. A brief introduction to the SOLO taxonomy model is presented in the data analysis section.

\subsection{The planned assignment}

Three steps were followed in implementing the action research cycle. First, the students were provided with the required theoretical knowledge on the above-mentioned topics, through interactive lecture sessions, during which students were asked to form small groups and informally interview each other to identify accounting decisions from their own personal lives (Figure 1). This social constructivist approach promoted student interaction (both lecturer-student and student-student), and allowed the lecturer/researcher to link the lecture topics to the students' lives. Lectures were partly framed and conducted based on the students' own findings, with particular concepts applied, i.e. incremental/relevant cost analysis, decision-making models, and qualitative factors in decision-making, to help them to analyse their own findings.

In order to translate their personal experiences into management accounting knowledge and relate them to the application in a management accounting context within organisations, the students were then asked to compare and contrast their personal experiences (constructively discussed above) with the actual business contexts. In order to facilitate this task, following an 'objectivist' approach (see Ancelin-Bourguignon, 2019), several mini-cases from the recommended text book, i.e. incremental/relevant costing techniques and the importance of qualitative factors in business contexts, were discussed in the class. The final quarter of the lecture was then spent on summarising the topic learning outcomes.

Second, the students were asked to submit a 100-word plan (in advance of Semester 2), stating the types of decisions they were going to investigate, the ordinary people (nonaccountants), e.g. family members or relatives, they were going to interview and how they would manage the interview process. They were advised to include a timeline for the entire piece of work, explaining their strategy for meeting the assignment deadline. They had to submit this plan in the middle of the autumn term (Semester 1) and the final coursework was due at the end of the spring term (Semester 2). A workshop was conducted in the sixth week of the autumn term (Semester 1) to provide an opportunity for further consultation with the course lecturers and tutors before the proposed fieldwork was then to be conducted during the 
Christmas and New Year holidays. In the final and critical step, students were asked to produce an individual report of 1500-1800 words, as presented in the methodology section.

The coursework question was as follows: "Consult between 6 and 8 people known to you and identify any major decisions they have made in the recent past (i.e. past 6 months). Conduct an in-depth interview, focusing on the objectives, steps and criteria they used to make their decisions. Then, critically and comparatively analyse their objectives and any alternatives they considered, what decision-making rules they followed, what incremental costs were concerned with those decisions, and what qualitative factors were involved in the decision analysis. Finally, compare and contrast the behaviour of these decision makers and identify the decision-making model/models each one adopted (e.g. rational, bounded rational, political). Explain the reasons for your judgments." This question was designed to get the students to understand how management accounting concepts can operate beyond work organisations, and in particular in people's everyday lives, and how those concepts interact with financial and also non-financial and social elements, i.e. emotions, family interests, throughout people's decision-making processes. This would then encourage students to integrate the concepts learned throughout the course. This radical constructivist approach required them to analyse ordinary people's economic decisions, made to achieve various livelihood objectives, and analyse any identified critical issues involved with their decisions. In terms of the teaching resources and guidance, the detailed guidelines on the purpose and methodology of the assignment were provided through an introductory session/workshop that took place at the end of Semester 1. Additional queries/issues relating to the coursework were answered at the end of regular lecture sessions and by e-mail. All the assignment guidelines and related lecture notes were uploaded onto "Blackboard", the virtual learning website of the university. The students seemed to respond positively to the concepts, as they asked very constructive questions. Finally, a presentation structure was proposed during an interim workshop organised in the semester 2. The structure was left open and flexible so as to accommodate creative adaptations and modifications (Figure 2).

In order to ensure that the deep learning tasks (based on principles of radical constructivist epistemology) were properly encouraged (see e.g. Vygotsky, 1978; Entwistle, 1988; Beattie et al., 1997; Biggs, 1994, 1999, 2003; von Glaserfeld, 1989; Hardy \& Taylor, 1997; von Glaserfeld, 2013), the educator displayed a genuine personal interest in the subject throughout, confirming that the students had enough time to discuss key concepts during 
lectures (using practical everyday life examples) and encouraging them to ask questions by email to clarify any misconceptions. The educator also attempted to create an active learning environment through student-student (e.g. small group discussions) and student-lecturer (e.g. answering individual questions) interactions, based on social constructivist principles, during lectures and practical tasks related to the assignment (e.g. interview data collection). As the assessment itself required careful thought, analysis and evaluation of people's behaviour, the students had to combine a variety of ideas (e.g. to compare and contrast behaviour). Because of the radical constructivist nature of the coursework design, they were free to choose their own interviewees and interview topics and were expected to use previous knowledge (e.g. decision models and cost concepts, personal experiences) in a new context (i.e. interviewing people). This freedom of choice on interviewee selections and interview topics and the informal support and encouragement provided by the two educators have made the students authentically interested and intrinsically motivated to engage in this form of learning. They were given plenty of time to identify and correct mistakes prior to finalising the work (without any penalties). The educator made it clear to the students that his guidance and marking scheme would be consistent and fair in assessing the declared learning outcomes. The students were clearly informed that marks would mainly depend on the interviews, methodology, analysis and reflective discussion parts of the report.

\section{Research methods}

\subsection{Aligning the teaching cycle design and student feedback with qualitative methods}

The teaching cycle in this study included an experimental form of educational practice (constructively learning from ordinary people without any previous accounting knowledge) in the first phase, followed by critical reflections on its successes and failures in the second phase. The approach offered a way of working that linked educational theories such as radical constructivism, with practice, into one whole: ideas-in-action, the aim being to improve the quality of teaching and learning actions within accounting education to help students to achieve deep learning outcomes. In particular, as the teaching cycle was conducted by, with and for students, rather than on students (Elliott, 1991; Reason and McArdle, 2007), the hope was to create a democratic environment for increased collaboration between all "stakeholders", namely students, staff and administrators, involved in the inquiry process and to provide opportunities to construct a grounded knowledge of the learning environment directly relevant to the issues being studied (Hudson et al., 2003). For example, in the 
planning stage, detailed guidance on how to conduct interviews was not initially included. It was expected that students would receive that knowledge from the subsequent research methodology module and through their life experiences. Based on student requests and feedback after stage one (the first workshop), however, an interview training and guidance component was added to the coursework plan. Also, at the beginning there were no restrictions on who should be included in their sample of interviewees. However, as a result of too many queries from students and the apparent inconsistencies in their sample selections, it was subsequently decided to provide specific instructions on whom to include in their samples. Based on the views of Hudson et al. (2003), it is hoped that these intrinsic connections between the stakeholders, e.g. students and educators, have made this current teaching cycle more reflective and critical and helped the educator to better understand the actual learning context of these management accounting students, with a view to suggesting improvements.

As a part of the teaching cycle, the educator integrated the interpretive paradigm and qualitative research methods, within the teaching cycle tasks undertaken by the students. This consisted of adopting an ethnographic approach facilitated by interviews and observations with home accountants (Davies, 1999; Hammersley \& Atkinson, 2007; Hammersley, 2014). In addition, the educators' reflections on the planned cycle of action for this research was based on informal interviews, participant observation of student learning activities and tasks, and fieldwork notes about student reactions and responses, so as to subjectively analyse the students' experiences, knowledge and perceptions. Adopting the interpretive paradigm and qualitative research represents an attempt to create a radical constructivist approach to learning and to reflect the behaviours of both home accountants and students in a natural setting (Brewer, 2000). As the constructivist and qualitative approach essentially led to the deep learning experiences of students, it was thought appropriate that the student feedback should also come from a similar perspective. The other belief was that it would be difficult to assess any cognitive learning exercise solely by adopting a quantitative method such as a questionnaire with closed questions (e.g. multiple choice).

\subsection{Data analysis method}

The study applied the SOLO taxonomy (Biggs and Collis, 1982; Biggs, 2003; Biggs and Tang, 2007) for its data analysis, as it provided a normative structure for the identification of variation in students' understandings of teaching cycle tasks, and in particular to illustrate and 
analyse the contextualisation (or de-contextualisation) of SOLO descriptors within the selected management accounting programme. Thus, based on Biggs and Collis (1982), Biggs (2003) and Biggs and Tang's (2007), the SOLO taxonomy (Structure of Observed Learning Outcomes) and the constructive alignment model are important for educators to study and align learning objectives, activities and to finally assess the learning outcomes in accounting programmes, modules and teaching cycle tasks.

The SOLO taxonomy describes the increasing level of complexity of a student's understanding of a subject, through five stages (namely, pre-structural, uni-structural, multistructural, relational and extended abstract), and is claimed to be applicable to any subject area (Table 3). However, not all students get through all five stages, and indeed, not all teaching (and even less "training") is designed to take them all the way. In other words, the use of the SOLO taxonomy provides a normative structure for the identification of the variation in students' understanding (Duff and McKinstry, 2007; Lucas and Mladenovic, 2009). Research findings (e.g. Campbell, 1998; Sims, 2006) indicate that to promote a student's understanding of a subject, all the following factors are required: instructional methods; personalised teaching (e.g. small groups); greater faculty-student and studentstudent interaction (social and academic); active and interactive teaching methods (e.g. case studies) based on constructivist epistemology; explicit discussions of learning/teaching skills (clarity and openness); and encouraging student input into module goals and methods (flexibility).

The qualitative content analysis of the students' coursework documents was the main method used for this evaluation (Downe-Wamboldt, 1992; Schreier, 2012). By using this method, the educator made subjective interpretations on the students' coursework content of text data and interview narratives, through a systematic classification process of coding and identifying themes or patterns, based on SOLO taxonomy features (Biggs and Collis, 1982). It helped the educator to identify variations in students' understanding of disciplinary concepts in the marking guide, and then categorise the potential deep and surface outcomes from the radical constructivist teaching cycle. For example, the current study looks at how the students' approach to learning and the narrative analyses presented in coursework content, reflect SOLO descriptors, particularly when they contextualised relevant management accounting concepts, e.g. relevant costing. First, how do they identify and name one or a few aspects of the underlined management accounting concepts and tasks? Then, how do they combine and 
describe them using their skills? Next, how do the students apply the concepts and make critical arguments in their findings? Finally, how do they create propositions and reflections, based on their theoretical understanding? Overall, the parameters from the SOLO descriptors were also used to measure the students' specific learning outcomes from the radical constructivist teaching cycle and to understand the extent to which the students achieved the educator's expectations, i.e. engagement with the context specific nature of accounting and the reasoning required to support their explanations. Both educators involved in teaching the management accounting module conducted the marking and qualitative content analysis of the students' essays. Both have expert knowledge of qualitative data analysis through previous case study research and interdisciplinary work experience. For example, both lecturers have published articles in sociologically oriented accounting research. A description of the hierarchical levels and categories identified for the current study (through the lens of the SOLO taxonomy) and their connections to the topic learning outcomes, is provided in Table 3. In addition, the inter-rater agreements about coursework marking, developed in association with the SOLO taxonomy and the learning approaches used by the students, are presented in Table 4.

The underlined assumption was that the students who display uni-structural and multistructural levels of learning can be seen as adopting a surface approach to learning while those who display relational and extended abstract levels of learning can be seen as adopting a deep approach to learning (Biggs and Collis, 1982). The analysis using the SOLO taxonomy involved the categorisation of responses into the predetermined categories shown in Table 4. The coursework answers were categorised following independent analysis by the two educators. In the qualitative content analysis (to identify the student performances and various learner categories), the student responses were reviewed, with a focus on identifying any trends or repeating patterns in their narrative analysis of interview transcriptions (presented in the coursework content). It was expected that the reflections from the students' narrative analysis would demonstrate their understanding of what the question asked and the underlined management accounting concepts they learned. This process helped to rank the coursework answers (Table 4) from descriptive to integrative for the purpose of critically analysing student learning approaches and topic learning outcomes. Any potential discrepancies in inter-rater classification were resolved through discussion between the two educators involved. 
In order to maintain the reliability (stability, reproducibility and accuracy) of the inter-rater agreements and the qualitative content analysis of coursework essays (Downe-Wamboldt, 1992; Krippendorff, 2004; Schreier, 2012), detailed model answers and general guidelines (for the allocation of coursework marks) were also provided to the two educators (coursework markers) and some discussion took place before, during and after the marking process. The allocation of marks in key areas is presented in Table 4. The marking scheme was designed to identify the following aspects: (i) whether the students had used the concepts with the proper meaning and understanding; (ii) how they had conducted the interview process; (iii) the number of interactions they had had with the interviewees; (iv) how they had distinguished between argument and evidence and linked them to the central question of the assignment. Finally, an attempt was made to determine whether the students had actively related the course content to real life (both the interviewees and their lives), which was the main purpose of this radical constructivist coursework. In order to maintain the reliability of inter-rater agreement, a discussion was held between the two educators after a sample of five student essays had been marked by each. Afterwards, every piece of coursework was secondmarked (by the other educator) to ensure accuracy and consistency in the marking. For instance, through careful analysis of the students' coursework, an attempt was made to find out how many of them had focused on the central question of the assignment and how many had applied the appropriate concepts (as previously and or newly learned) in their analysis. Overall, the marking and qualitative content analysis of the coursework were both aimed at identifying evidence of creative thinking, critical analysis and radical constructivist interpretations, as the central themes of successful student approaches to learning (von Glaserfeld, 1989; Hardy \& Taylor, 1997; Duff and McKinstry, 2007; von Glaserfeld, 2013). It was also expected that this evidence could help the researcher to "analytically generalise" the study findings (Yin, 2003). In analytical generalisation, qualitative researchers argue that case study findings from one particular context can be generalised to other similar contexts.

In addition, informal interviews/discussions with selected students were used to obtain feedback "narratives" from the students' perspective. This involved selecting two opinion leaders (always asking questions), two enthusiastic students (regularly attending classes), two easy riders (who regularly missed lectures) and two students who did turn up regularly but were neither opinion leaders nor enthusiastic ("silent behaviour" in the class), so as to gain views from a range of student personalities (and, potentially, different learner types). These students were selected using cluster sampling, combined with the researcher's first-hand 
knowledge of student behaviours in the class, i.e. regular attendance and participation in the lectures and class room exercises. In addition, the attendance registers were used to monitor the students' commitment to class room learning. After identifying the clusters based on unique behavioural patterns and personalities (opinion leaders, enthusiasts, easy riders, silent), the researcher randomly selected two from each cluster for the interviews. The purpose of using cluster sampling was to help the researcher obtain feedback from the relatively homogeneous and natural groupings, and collect feedback representative of the diverse personalities of the students under study (Kelly, 2006). This method was preferred over a survey, because the qualitative interviews with superficially selected students helped the researcher to motivate the students to give more active feedback on their experiences. However, at the end of the course, a survey was also conducted using a standard feedback form. It also encouraged students to provide their feedback on the overall assessment methods used in the Management Accounting module.

The feedback narratives from qualitative interviews were then analysed using the narrative analysis method (Reissman, 1993). The educator carefully analysed the interview responses of the management accounting students, in an attempt to understand the relationships between their coursework experiences and the teaching and learning environment. To achieve this, the educator grouped the interview data around the main study themes. In the interviews, three open-ended questions were asked to find out the students' general opinions about the coursework, any problems they had faced, and suggestions for improvements. The narratives were then analysed in order to understand the students' meanings and their overall perceptions about the assigned deep-learning activities. The feedback interviews with the students were conducted after they had submitted their coursework and also after the final examination (most were done at the beginning of the next academic year), in order to avoid any potential bias/influence created by the researcher's personal investment in the project and to ensure that the students did not feel constrained that they might harm their grade if they said the wrong thing. Moreover, support was obtained from the co-educator and a few tutors [graduate teaching assistants (GTAs)] who had delivered the seminars and administered the module. They conducted half of the interviews to avoid bias in the interview responses that would be caused by a single interviewer.

The student feedback narratives were compared with their individual (and overall) performance on the coursework. Moreover, the formal feedback obtained through the 
departmental "module feedback forms" was also used as evidence to measure the students" perceptions of the module teaching and coursework assessment, and in particular to crossexamine the interview narratives and themes. Finally, participant observations of student behaviour (e.g. active participation and attendance) in the module (during lectures/tutorials/coursework) were used to inform the feedback-taking process (e.g. identifying easy riders). These so-called "other types of student performance" were also monitored/observed by the co-educators and the module tutors. Regular discussions were held with them to find out their personal reflections and about their class experiences.

\section{Findings and reflections from the teaching cycle}

\subsection{Students' module and topic learning outcomes}

In order to assess the students' module and topic learning outcomes, the coursework submitted by the students was first- and second-marked anonymously. The distribution of marks was analysed to obtain an initial assessment of the students' performance. According to the overall statistics, the mean mark given was 52.14 with a standard deviation of 9.362 (see Table 6 for the classification of marks). In general, the coursework methodology and marking received positive comments from the external examiner and were also praised by some of the senior colleagues in the School of Management and Business. For example, one colleague remarked: "You must make a presentation to the whole school on this. We must encourage this type of coursework in other modules and departments." With such encouraging feedback, it was decided to repeat the same coursework (with further improvements) in the following year.

As was shown earlier (Table 5), the highest marks were allocated to the discussion and analysis and evaluation sections (55\% of marks). This had a significant impact on the final marks and the students' grades, as shown in Table 6. The SOLO taxonomy and inter-rater agreements (Table 4) were used to mark (and rank) the discussion and analysis sections of the coursework. Accordingly, students who received low marks (49\% or below) had reflected uni-structural or low multi-structural levels of competence. In fact, they had produced highly descriptive analysis sections, mostly focusing on one decision-making model or only a few aspects of the relevant cost concepts. The students in the 50 to $59 \%$ bracket had shown high multi-structural but low-level relational competence, having comparatively analysed various decision-making models and relevant cost accounting practices in many related aspects and elaborated each point with illustrations/case study examples but only in a few parts of the 
essay. In contrast, the students in the 60 to $69 \%$ bracket had extended their discussion of the above models and practices with examples throughout the whole essay. They had reflected a greater attempt to achieve high-level relational competence by making overall analytical generalisations of the major concepts (decision-making models/accounting techniques) learned in the module. Finally, the students who obtained $70 \%$ and above had consistently reflected the connections between the decision makers' life choices, decision criteria and accounting language, and attempted to theoretically generalise their ideas throughout the essay. Some of these students even presented their self-reflections by relating some of the interviewees' experiences to their own lives. In fact, by showing their competence in developing extended abstracts and interpretations, some of them had even made and asked reflective and critical comments and questions about the underlying decision-making assumptions and techniques they had learned in the module. This has demonstrated the significance of adopting radical constructivist learning approaches, since these students had the freedom to actively learn, unlearn and question, the basic assumptions behind the topic being learnt. Overall, the majority $(62 \%)$ of the students received $50 \%$ or more and achieved a high level of multi-structural competence and low relational competence regarding decision-making models and relevant cost techniques. $18 \%$ of the students achieved $60 \%$ or more and gained high relational competence on the above models and concepts and some knowledge on reflectivity and analytical generalisation (extended abstracts).

Alternatively, the final written exam (70\%) was comprised of all numerical questions with interpretative elements, including a few questions attaining detailed and descriptive information on the chosen exam topics. Its results presented in Table 6 demonstrated that $40.9 \%$ of students in this module have obtained the written exam marks above $60 \%$. level (second class - upper or first class), while only $18 \%$. reported having similar marks to the coursework element. On the other hand, more failures (10.71\%) were reported in the written exam than in the coursework marks (4\%). This reflected the difficulty of establishing a direct link or relationship in the grades between the two parts. Moreover, in the overall exam marks, only $8.9 \%$ of student reported as failures. Based on these results it seemed difficult to imagine that the $30 \%$ coursework had any direct impact on the surface learning students' pass rates. It appeared that the $70 \%$ weight of the written examination might lead to re-evaluation of the percentage between the examination and the coursework. In fact, more students were performing better in the coursework with more constructivist elements than the written examination. It can be argued that these learning outcomes resulted 
from the students' constructivist approaches to learning and their perceptions of the task environment (Duff and McKinstry, 2007). Of these, first, an analysis of the students' approaches to learning is presented below.

\subsection{Students' approaches to constructivist learning}

The qualitative content analysis results indicated that there were three main student groups, based on learning strategies that could be recognised from the narrative contents of the essays. As presented in the above section, three main levels of learning outcomes were achieved in the assessment: (I) high relational skills and some skills in developing extended abstracts (18\%), (II) high multi-structural and low relational skills (44\%), and (III) unistructural and low or moderate multi-structural skills (38\%). According to Duff and McKinstry (2007), this reflects the relatively different approaches to learning adopted by management accounting students.

Group I (ranked 6-7) students were mainly creative, insightful, critical, reflective and methodical, and had an extended abstract knowledge of the meanings of concepts and the application of appropriate theory to data analysis. Many had successfully analysed their findings by combining various aspects of the decision-making models and incremental cost analysis. They also provided extensive evidence from core and associated readings in recommended text books and academic research papers. They managed to clearly distinguish between argument and evidence, and comprehensively focused on the central question. Their interview process was well managed, with good organisation, interaction and reflections. Many of them had logically and carefully planned their interviews with "non-native speakers of accounting" (people without any previous education in or experience of accounting) and conducted lengthy and constructive interviews. They linked the course content to everyday life with appropriate examples and even used many relevant narrative accounts to support their analysis and conclusions, thereby demonstrating their radical constructivist approach to learning (von Glaserfeld, 1989; Hardy \& Taylor, 1997; von Glaserfeld, 2013). Finally, they were very careful to make excellent presentations that were well-structured and used an appropriate, academic style of writing. This group appeared to have taken an in-depth approach to completing the task.

Group II students (ranked 3-5) showed sound knowledge of the essential material, a reasonable understanding of accounting theory and some level of analytical ability. Their 
attempts were generally matched to the coursework question and were generally accurate, including predominantly, the correct use of methods and techniques (where relevant). Many of them managed to analyse their findings by combining various aspects of the decisionmaking models and incremental cost analysis but showed a low level of interest in comparing and contrasting different decision-making models and relevant cost concepts. They had conducted the fieldwork interviews with some determination and showed some evidence of genuine effort and social constructivist approach to learning (e.g. a reasonable number of interviews of a good length that reflected some analytical abilities, appropriately linking the interview data to the incremental costing theory and appropriate decision-making models). Overall, this group appeared to be deep learners. However, a subset of this group that had only paid attention to the methodology and analysis sections. Their answers contained occasional mistakes and/or information that was not well organised and presented. There was some evidence that they had done the recommended reading and accessed other relevant materials but only a few had gone beyond the core reading. These learners seem to be very much closer to the category of pragmatic constructivists (Jacobson et al., 2019). This group were also somewhat careless in their organisation and presentation. For example, they made some mistakes in their referencing. Thus, it appeared that this group took a strategic approach to completing the task, reflecting the characteristics of strategic learners. They seemed to have a certain mark in mind and to be just trying to achieve that.

Finally, the main features of group III students (ranked 1-2) were sparse case notes and an absence of clear focus, theory and analysis. Their work was often accomplished with tabular analysis and less with textual explanations. While they made serious efforts to combine various decision-making models and relevant cost concepts in the essay, they showed very little interest in going beyond that level and comparing and contrasting those models and concepts or identifying their diverse applications in practice. They showed an inability to make (or less interest in making) critical interpretations with appropriate links to decision models and accounting theory (e.g. incremental costing). Their work was more descriptive than analytical and often had little relevance to the essay question. There was not much evidence of their having reviewed relevant materials outside the core reading. Their interview process was weak and they managed to conduct only a few interviews (below the required number and of less quality). The length of their interview notes showed weaknesses or inability to do organised work with a clear focus. Their essays were poorly organised and inconsistently presented. Often it was noticeable that they had reproduced the class notes and 
incorporated their case notes into the body of the report in order to achieve the word limit. Overall, this group reflected an inability (or lack of genuine effort) to link the course to everyday life. To the lecturer/researcher, this group appeared to take both the surface and strategic approaches to completing the task.

The findings from the above qualitative content analysis also reflect the complexity involved in recognising and distinguishing learner categories. There were significant differences and overlaps (both strategic and surface learners in one group) between and within these three student groups. Since learner characteristics are qualitative and closely related to the individual's motivation in the particular context (Ramsden, 1992; Campbell, 1998), it is obviously difficult to draw clear-cut boundaries between these groups. However, regular observations of student behaviour, coupled with a close examination of the coursework, provided a complementary mechanism to support and validate the above relative categorisation. For example, regular observations confirmed that the easy riders (students who regularly missed lectures and tutorials) were mostly in the surface learner category (group III above). Such students often collected handouts from fellow students, accessed course information from the Blackboard virtual learning facility, and seemed to have tried to work out how to pass the coursework rather than engaging in any academic interaction with fellow students or the lecturer. According to accounting education scholars, students' approaches to learning are also affected by their perceptions of the task environment (Duff and McKinstry, 2007). Thus, an analysis of the management accounting students' perceptions of the assessment task is presented below.

\subsection{Students' perceptions of radical constructivist task requirements}

The students must show some enthusiasm and motivation from their side if they want to participate in, and achieve, deep learning through a constructivist approach (Biggs, 1994, 1999, 2003; Biggs and Tang, 2007; Ancelin-Bourguigon, 2019; Jacobson et al., 2019; Jack \& Saulpic, 2019). This requires an intrinsic curiosity in the subject, a determination to do well, mental engagement in academic work, appropriate background knowledge and experience to provide a sound foundation, the time to pursue specific targets through good time management, and a positive prior experience of education that has led to confidence in their ability to understand, reflect and succeed. In addition, Duff and McKinstry (2007) state that specific student factors (i.e. prior knowledge, motivation and affect) as well as the learning context (i.e. intended learning outcomes, teaching and learning activities and assessment 
tasks) have a big impact on students' perceptions of task requirements and thereby, on their approach to radical constructivist learning.

On this note, based on the educator's observations, it would appear that the students who performed poorly in this Management Accounting module (mainly those in group III) generally lacked these individual qualities (student factors). For example, these students on this module displayed different types of motivation, rationalisation and reflective monitoring of their actions. The diverse motivational levels expressed by deep, surface and strategic learning categories of students engaged in the module, reflect different types of commitment to constructivist activities, rather than a lack of understanding of the learning objectives set by the educator. Their motivation determined their potential and commitment to accomplish the radical constructivist actions required for the coursework. The findings show that most students rationalised their coursework actions via their theoretical understanding of the basis of learning activities, rather than any planned misinterpretation. Many of them had rarely asked questions in lectures or tutorials, in spite of the lecturer's repeated encouragement to do so (no intrinsic curiosity); they failed to regularly attend lectures and tutorials or attempt tutorial questions, regardless of advice and warnings (no determination to do well); and/or they started the interview process too late and made last-minute enquiries about the essay question, again despite regular reminders (poor time management). By contrast, the students showing satisfactory performance in terms of deep learner characteristics (mainly in group I and some in group II) showed they had adopted the correct developmental and constructivist approach, by constructively engaging with their research subjects, generally producing good reflective reports and case summaries. Overall, this group of students demonstrated a high level of motivation in terms of attending and asking questions in class. They all reflexively monitored their own actions, not only observing and reflecting on themselves but also on other students and home accountants (interviewees), and on the contexts, both social and physical, through which the learning activities took place. Thus, benchmarking and choosing their own level of performance by constructively looking at other students, was a common practice among the accounting students in this teaching cycle context. These behaviors indicate the potential for the introduction of more social and/or radical constructivist teaching cycles and activities to management accounting learning.

Next, informal interviews with selected students were specifically employed to assess student perceptions of the radical constructivist coursework tasks. As an understanding between the 
students and the educator had already been established, the selected student interviewees were enthusiastic and keen to provide feedback. A few general and open-ended questions were asked and students were given the freedom and flexibility to provide detailed answers. Importantly, they were invited to make critical and constructive comments, and overall, some interesting and useful views were reported. For example, the following narratives/statements made by the student interviewees reflected positive attitudes and optimistic feelings and perceptions regarding the assignment. One remarked: "I really enjoyed this assignment. It is different to our previous experiences. It is good to meet people and share their experiences. Actually, I learned accounting from non-accountants." Another enthusiast (a student previously identified as "enthusiastic") said: "It is a creative assignment. By doing it, I learned many things for the future. Not only about accounting but how to interview people, analyse interview data and write reports. Even my family enjoyed it, as I interviewed them."

One of the "opinion leaders" interviewed said: "Always I like practical work. It promotes our thinking. It trains us how to apply and test the things we learn. Main thing is this exercise is not boring. Actually, I had some doubts when this was introduced. But everything was cleared [up] after the workshop session." Another "opinion leader" commented: "The assignment is good. I tried very hard to do it [to] my best. But I am not fully happy. I should have done a better analysis. I think we need[ed] pre-training for the data analysis - I mean before the coursework. But this is a useful and innovative assignment. I love it. I know many enjoyed it." While such views presented by the enthusiastic students and the opinion leaders were almost inevitably positive and constructive, the content of these statements also clearly shows the individual characteristics of deep learners, as they were all happy and motivated to learn by doing innovative and social or radical constructivist tasks in their coursework. This reflects an intrinsic motivation and curiosity from their individual perspective. The statement made by one of the opinion leaders, "The assignment is good. I tried very hard" in particular showed his/her desire/hunger to learn and a dissatisfaction and self-criticism about his/her own work.

In contrast, the following comments made by the student interviewees represented more pessimistic and mixed feelings and perceptions about the coursework assignment. For example, one opinion leader remarked: "It is different but difficult. Time consuming. In the second semester we have more coursework (for other subjects). I think it is ideal to do it in the first semester". Another said: "It is good to do as a group work. I am not good at talking 
to people but I can write and analyse. It [would have been] good if I had [had] someone to conduct the interviews." One student was constructively critical about the coursework, saying "I think you should give the marking scheme in advance. Maybe with the assignment guidelines. Then, we can plan and work to get good marks." One of the easy riders interviewed emphasised all the negative aspects of the assignment: "It is quite challenging. Interviewing people and selecting appropriate questions is not easy. It is time consuming and hard work. We need some experience to do that." One student who turned up regularly to the class but could not be considered either an opinion leader or enthusiastic, said: "I just attend the classes because of the $80 \%$ attendance rule. I don't mind about the assignment as long as I can get the pass mark." The above comments mainly highlight the characteristics of surface (and also some strategic) learners who are searching for and adopting ways to avoid a heavy workload and any new work (in other words, they organise things strategically so as to manage their workload). Hence, their emphasis on other than academic factors reflects their extrinsic motivation when doing the assessment tasks (Biggs, 1994; Biggs and Tang, 2007). In particular, the comment made by one of the students: "I think you should give the marking scheme..." reflects strategic learning to the extent that he/she indicates the importance of being organised about earning marks and passing the coursework, and possibly that he/she is primarily motivated by a fear of failure (Biggs, 1994; Biggs and Tang, 2007). Finally, another student commented about her concern of relative performances of fellow students in the class: "I feel like most of the others did well, better than me. They found it easier to contact interviewees (family members), as most of them are native people (but I am from a foreign country)". This reflects the diversity of student perceptions and their behaviour of comparing their work with other agents in the same context.

These comments offer very important insights for future coursework design, whether in a similar exercise in the same context or implemented elsewhere. They indicate adjustments that could be made to encourage surface learners and motivate them to become deep learners by engaging with constructivist learning approaches. For instance, the inclusion of a general marking scheme/assessment information in the coursework guidelines (e.g. sectional marks), a special training session on interviewing skills (e.g. a tutorial), confidence-building talks (e.g. explaining this year's experience) and refining some aspects of the coursework (e.g. a different context) may need to be considered. On the other hand, their view that "it is different but difficult" reflects the greater challenge created by this coursework and the students' lack of familiarity with this type of assignment. These feedbacks and participant 
observations of student behaviour in this Management Accounting module also reflect that some students had contextual (e.g. social, physical) limits, in terms of their capacity to pursue and accomplish a multiplicity of learnings in the context of conflicting and complementing assessment tasks that often intersect or run in parallel and may be either continuous or disconnected in time (e.g. different modules and pieces of coursework in one semester). Thus, it was challenging for the educator to understand particular student factors such as individual behaviours and shortcomings simply through this one specific radical constructivist coursework activity. There is a great need for educators to actively engage in managing assessment tasks and teaching and learning activities, and to educate the students in how to better execute their individual fieldwork plans, if they wish to create favourable student perceptions of task requirements (Duff and McKinstry, 2007).

However, it has to be noted that giving a marking scheme may also violate the fundamental assumptions of the deep learning approach and the constructivist epistemology, as the latter require more of an open learning environment to encourage students' creative thinking, analysis and logical interpretations and reflections, rather than controlling them (e.g. through a marking scheme) in a narrow direction. On the other hand, by not providing a marking scheme or detailed guidelines, there may be a risk of losing (or not achieving) the learning outcomes of the constructive learning exercise. Therefore, it can be argued that constructive learning methods require relatively experienced educators to deal with the constructive environment and to maintain a balance between the learning outcomes and the constructive nature of the exercise. Similarly, any such innovations should be planned very carefully and the learning outcomes tested regularly. The educator must also construct and analyse narratives (interview excerpts) carefully, without manipulating the meanings given by the students. For example, the narratives/statements of this study reflect how the learning experience was perceived differently by different students, on the basis of their particular student factors such as intrinsic motivation (Duff and McKinstry, 2007). Some students value quantitative factors, such as increasing knowledge, memorising information and acquiring facts, whilst others attempt qualitatively to make sense of what they learn, and try to constructively understand different social realities (see Saljo, 1979).

\section{Conclusions}

This paper has reported the findings of a radical constructivist teaching cycle that sought to create a constructive environment for students' interactions with non-accounting people 
beyond work organisations, e.g. home, community to achieve deep learning outcomes (Marton \& Saljo, 1976; Marton and Saljo, 1976; Biggs, 1999; Von Glasersfeld, 1995, 2013; Paisey \& Paisey, 2005; Boyce et al., 2012; Fordham, 2012; Stanley \& Marsden, 2012) within management accounting education, via a UK university's second-year (level 2) Management Accounting module. It was motivated by the growing trend for accounting educators to adopt a constructivist philosophy and apply qualitative methodology in management accounting education (i.e. learning with understanding) (Vygotsky 1978; Hardy \& Taylor, 1997; Gash, Steffe \& Thompson, 2000; 2014; Riegler \& Steffe, 2014; Ancelin-Bourguigon, 2019; Jacobson et al., 2019; Jack \& Saulpic, 2019). These researchers state the benefits of constructivist epistemology as it makes learning an active, constructive, intentional, complex, contextualised, reflective and collaborative exercise and encourages learners to construct reflective dialogue and meanings by themselves through relevant learning activities (Fosnet, 1996; Biggs, 2003; Chapman et al., 2005; Duff \& McKinstry, 2007; Lucas \& Mladenovic, 2009). However, these previous constructivist studies were limited in their focus toward social or pragmatic constructivist approaches to management accounting education rather than involving any and there was a lack of experimentation within a teaching cycle applying a radical constructivist perspective. This study has addressed this gap in the management accounting education literature. Accordingly, to find out on what extent management accounting educators should construct a 'radical constructivist' foundation to guide active learning, the designed teaching cycle invited a cohort of level 2 management accounting students to analyse and evaluate certain decision scenarios from people's everyday lives, using accounting concepts (see Gallhofer \& Chew, 2000; Jacobs \& Kent, 2002; Jacobs \& Walker, 2004; Jayasinghe \& Wickramasinghe, 2007). Then, to understand what ways management accounting educators can use qualitative approaches to facilitate 'radical constructivist' education, the study adopted an ethnographic approach consisting of informal interviews, participant observations, qualitative content analysis and narrative analysis (Davies, 1999; Hammersley \& Atkinson, 2007; Hammersley, 2014; Downe-Wamboldt, 1992; Schreier, 2012) to create a constructivist learning environment for the students (e.g. interviewing home accountants), and also for educators, to investigate and analyse student learning outcomes and obtain feedback.

The study findings and reflections contribute to both the theoretical and empirical literature on deep learning through constructivist epistemology (see Wilson \& Cole, 1991) in management accounting education in three specific ways. First, the study findings illustrate 
that the majority of students respond positively to radical constructivist learning if the educators can develop an innovative problem-solving and authentic environment close to their real lives, such as the one created by this study's teaching cycle. Second, the study's radical constructivist teaching cycle has challenged the minds-sets of management accounting students since it altered traditional objectivist academic learning approaches they had encountered in the past. In particular, the study's use of qualitative methodology provides an alternative to the orthodox quantitative and objectivist approaches that still prevail (e.g. questionnaires) in mainstream education (see Jack \& Saulpic, 2019). The integration of qualitative methods with radical constructivist epistemology has not only provides authentic meaning to academic education, but also offers a form of control to students over there active learning. Finally, student feedback gathered through qualitative feedback collection methods such as informal interviews, participant observation and narrative analysis, has also provided a constructive mechanism for both students and educators to learn and unlearn from their mistakes, thereby enriching the understanding of learners (students) and the understanding of educators in terms of successfully designing future radical constructivist teaching and assessment programs. Importantly, the study reveals that the students as social agents were mostly motivated, rationalised and willing to reflectively monitor their agential actions in the constructivist learning process, while benchmarking and choosing their own level of performance by looking at fellow students in the program.

Largely, the study findings suggest that management accounting educators should act as change-agents in their own departments and introduce the constructive learning structures (roles, rules, mechanisms, etc.) and cultures (constructivist educational theories, beliefs, norms, etc.) associated with radical constructivist tasks in their teaching programs. Such an approach can facilitate active thinking, debating and arguing within management accounting students before acting and mobilising their individual capacities to achieve deep learning objectives. For example, by introducing management accounting as a broader phenomenon embedded in all social actions, both in organisations and society, and by assigning case study tasks to students to help them understand how accounting concepts and decision models apply in their own homes and communities, this teaching cycle made an attempt to deconstruct students' prior thinking that accounting was a technical private-sector-oriented practice. This made them aim for certain outcomes differently than in their previous deep learning experiences (although they were all attempting to achieve specified learning 
outcomes), to obtain certain results (although not always ones they liked) and to achieve certain ends (although not always through their preferred means).

However, it is a real challenge to all accounting educators to find the right balance between radical constructivist and objectivist tasks, in order to effectively manage both surface and deep learners in the same class. In fact, the accounting students in the current study reflected a mix of responses (both positive and negative) to the radical constructivist methodology. This raises the question of whether it is feasible to incorporate this type of assignment and get positive feedback and results from a certain type of students, e.g. surface learners. Thus, the findings of this study indicate that mere enthusiasm and optimism are not enough to produce positive learning outcomes through constructivist approaches combined with qualitative methodology. If accounting educators wish to be successful in creating and experimenting, to produce more teaching cycles contained with innovative learning elements that are relevant to the real world, they need to be very knowledgeable about these critical and interpretive epistemological insistences. This kind of coursework thus requires more time and commitment and knowledge and experience of qualitative research from the educator than more convenient, objectivist forms of coursework. Therefore, the educators themselves must express developmental and positive attitudes to ensure its success. It is also difficult to measure whether the students translated any of the skills developed through this radical constructivist coursework into their end of term examinations. Because of that difficulty, the two internal examiners (co-educators) intentionally avoided the sections covered by the coursework (incremental costing, decision-making models) in the later examination and therefore did not re-test coursework knowledge. Despite these empirical challenges, it is evident that the innovative learning discussed in this study managed to change the majority of the students' behaviour, for example in achieving certain learning outcomes, due to its radical constructivist nature. This should encourage accounting educators towards radical constructivist teaching cycles and embrace more innovative elements within management accounting education. In turn, this might lead to grounded reconstructions of how management accounting students can accomplish what they need to and how accounting educators can create constructive learning environments to support them in doing so. 


\section{References}

Abhayawansa, S. and Fonseca, L. (2010). Conceptions of Learning and Approaches to Learning-A Phenomenographic Study of a Group of Overseas Accounting Students from Sri Lanka, Accounting Education: An International Journal, 19(5), pp. 527-550.

Accounting Education Change Commission (1990). Objectives of education for accountants' position statement number one, Issues in Accounting Education, 5(2), pp. 307-312.

Apostolou, B., Dorminey, J., Hassell, J.W.J. and Watson, S.F. (2012). Accounting education literature review (2010-2012), Journal of Accounting Education, 31(2), pp. 107-161.

Ancelin-Bourguignon, A. (2019), "The priming role of qualitative research in constructivist management control teaching", Qualitative Research in Accounting \& Management, Vol. 16 No. 4, pp. 463-490. https://doi.org/10.1108/QRAM-10-2017-0100

Ballantine, J., Duff, A. and McCourt Larres, P.A. (2008). Accounting and Business Students' Approaches to Learning: A Longitudinal Study, Journal of Accounting Education, 26, pp. 188-201.

Beattie, V., Collins, B. and Mclnnes, B. (1997). Deep and surface learning: a simple or simplistic dichotomy? Accounting Education, 6(1), pp. 1-12.

Berelson, B. (1952). Content Analysis in Communication Research. New York: Free Press.

Biggs, J. (1994). Student learning research and theory - where do we currently stand? In Gibbs, G. (Ed) Improving Student Learning - Theory and Practice, Oxford: Oxford Centre for Staff Development. Available online at http://www.city.londonmet.ac.uk/deliberations/ocsd-pubs/isltp-biggs.html

Biggs, J. (1999). Teaching for Quality Learning at University: What the Student Does. Buckingham: Society for Research into Higher Education (SHRE) \& Open University Press.

Biggs, J. (2003). Teaching for Quality Learning in Higher education, $2^{\text {nd }}$ Edition. Buckingham: SRHE/Open University Press.

Biggs, J. and Collis, K. (1982). Evaluating the Quality of Learning: the SOLO Taxonomy. New York: Academic Press.

Biggs, J. and Tang, C. (2007). Teaching for Quality Learning at University, $3^{\text {rd }}$ Edition. Buckingham: SRHE and Open University Press.

Birkett, W. and Mladenovic, R. (2009). The Study Process Questionnaire: Theoretical and Empirical Issues for Accounting Education Research. In Baxter, J. and Poullaos, C. (Eds) Practices, Profession and Pedagogy in Accounting - Essays in Honour of Bill Birkett. Sydney, Australia: Sydney University Press, pp. 423-450.

Bloom, B.S. (Ed) (1956). Taxonomy of Educational Objectives, the Classification of Educational Goals - Handbook I: Cognitive Domain. New York: McKay.

Boyce, G., Greer, S., Blair, B. and Davids, C. (2012). Expanding the Horizons of Accounting Education: Incorporating Social and Critical Perspectives, Accounting Education: An International Journal, 21(1), pp. 47-74.

Brewer, J.D. (2000). Ethnography. Buckingham: Open University Press.

Bruner, J. (1986). Actual Minds, Possible Worlds. Cambridge MA: Harvard University Press.

Byrne, M., Flood, B. and Willis, P. (2009). An Inter-Institutional Exploration of the Learning Approaches of Students Studying Accounting, International Journal of Teaching and Learning in Higher Education, 20(2), pp. 155-167.

Campbell, E. (1998). Teaching strategies to foster deep versus surface learning, Teaching Options Pédagogiques [verified: 30th January 2005] http://www.uottawa.ca/academic/cut/options/Nov_98/TeachingStrategies_en.htm

Carr, W. and Kemmis, S. (1986). Becoming Critical: Education, Knowledge and Action Research. London: Falmer. 
Chapman, C., Ramondt, L. and Smiley, G. (2005). Strong community, deep learning: exploring the link, Innovations in Education and Teaching International, 42(3), pp. 217-230.

Cooper, B.J. (2004). The enigma of the Chinese learner, Accounting Education: An International Journal, 13(3), September, pp. 289-310.

Davies, C. A. 1999. Reflexive Ethnography: A Guide to Researching Selves and Others. London: Routledge.

Doran, J., Healy, M., McCutcheon, M. and O'Callaghan, S. (2011). Adapting Case-Based Teaching to Large Class Settings: An Action Research Approach, Accounting Education: An International Journal, 20(3), pp. 245-263.

Downe-Wamboldt, B. (1992). Content analysis: Method, applications and issues. Health Care for Women International, 13, 313-321.

Duff, A., Dobie, A. and Guo, X. (2008). The Influence of Business Case Studies and Learning Styles in an Accounting Course: A Comment, Accounting Education: An International Journal, 17(2), pp. 129-144.

Duff, A. and McKinstry, S. (2007). Students' Approaches to Learning, Issues in Accounting Education, 22(2), 183-214.

Elliott, R.K. (1991). Invited editorial: accounting education and research at the crossroad, Issues in Accounting Education, 6(1), pp.1-8.

English, L., Luckett, P. and Mladenovic, R. (2004). Encouraging a Deep Approach to Learning through Curriculum, Accounting Education: An International Journal, 13(4), pp. 461-488.

Entwistle, N. (1988). Styles of Learning and Teaching. London: David Fulton.

Flood, B. and Wilson, R.M.S. (2008). An Exploration of the Learning Approaches of Prospective Professionals in Ireland, Accounting Forum, 32, pp. 225-239.

Fordham, D.R. (2012). Applying a real-world fraud to multiple learning objectives: Considerations and an example from the systems course, Journal of Accounting Education, 30(3-4), pp. 325-354.

Fosnot, C.T. (Ed) (1996). Constructivism: Theory, Perspectives, and Practice. New York: Teachers' College Press.

Gallhofer, S. and Chew, A. (2000) "Introduction: Accounting and Indigenous Peoples", Accounting, Auditing and Accountability Journal, Vol.13, No.3, pp.256-67.

Geertz, C. (1988). Work and Lives: The Anthropologist as Author. Cambridge: Polity Press.

Giraud, F. and Saulpic, O. (2019), "Research-based teaching or teaching-based research: Analysis of a teaching content elaboration process", Qualitative Research in Accounting \& Management, Vol. $16 \quad$ No. 4, pp. 563588. https://doi.org/10.1108/QRAM-10-2017-0097

Glasersfeld E. von (1995) A constructivist approach to teaching. In: Steffe L. P. \& Gale J. (eds.) Constructivism in education. Erlbaum, Hillsdale: 3-15. Available at http://www.vonglasersfeld.com/172

Hall, T.W., Pierce, B.J., Tunnell, P.L. and Walther, L.M (2014). Heterogeneous student perceptions of accounting course importance and their implications for SET reporting and use, Journal of Accounting Education, 32(1), pp. 1-15.

Hammersley, M. 2014. Reading Ethnographic Research: A Critical Guide. London: Routledge.

Hammersley, M. and P. Atkinson. 2007. Ethnography: Principles in Practice, Third Edition. Abingdon: Routledge.

Hardy, M. and Taylor, P.C (1997), Von Glasersfeld's Radical Constructivism: A Critical Review, Science and Education 6, pp 135-150, Kluwer. Available 
at http://www.academia.edu/6183789/Von Glasersfelds radical constructivism A cr itical review

Hudson, B., Owen, D. and Van Veen, K. (2003). Working on educational research methods with Masters students in an international online learning community, European Conference on Educational Research, University of Hamburg, 17-20 September.

Jack, L. and Saulpic, O. (2019), "How qualitative research can infuse teaching in accounting", Qualitative Research in Accounting \& Management, Vol. 16 No. 4, pp. 457-462. https://doi.org/10.1108/QRAM-05-2019-0109. Copyright (C) 2019, Emerald Publishing Limited. All rights reserved.

Jakobsen, M., Mitchell, F., Nørreklit, H. and Trenca, M. (2019), "Educating management accountants as business partners: Pragmatic constructivism as an alternative pedagogical paradigm for teaching management accounting at master's level", Qualitative Research in Accounting \& Management, Vol. 16 No. 4, pp. 517541. https://doi.org/10.1108/QRAM-10-2017-0099

Jacobs, K. and Walker, S.P. (2004), "Accounting and accountability in the Iona Community", Accounting, Auditing \& Accountability Journal, Vol. 17 No. 3, pp. 361381.

Jacobs, K. and Kemp, J. (2002), "Exploring accounting presence and absence: case studies from Bangladesh", Accounting, Auditing \& Accountability Journal, Vol. 15 No. 2, pp. 143-161.

Jayasinghe, K. and Wickramasinghe, D. (2007), "Calculative practices in a total institution", Qualitative Research in Accounting \& Management, Vol. 4 No. 3, pp. 183-202.

Kelly, A. (2006) Cluster Sampling, V. Jupp (Ed) The SAGE Dictionary of Social Research Methods, DOI: http://dx.doi.org/10.4135/9780857020116

Kember, D. (1997). A re-conceptualisation of the research into university academics, Learning and Instruction, 7, pp. 255-275.

Krippendorff, K. (2004). Content Analysis: An Introduction to its Methodology, $2^{\text {nd }}$ Edition. London: Sage Publications.

Lowe, D.R. and Simons, K. (1997). Factors influencing choice of business majors - some additional evidence: a research note, Accounting Education: An international journal, 6(1), pp. 39-45.

Lucas, U. and Mladenovic, R. (2004). Editoral - Approaches to Learning in Accounting Education, Accounting Education: An International Journal, 13(4), pp. 399-407.

Lucas, U. and Mladenovic, R. (2009). The Identification of Variation in Students' Understandings of Disciplinary Concepts: The Application of the SOLO Taxonomy within Introductory Accounting, Higher Education, 58(2), pp. 257-283.

Marton, F. and Saljo, R. (1976). On qualitative differences in learning. I. Outcome and process, British Journal of Educational Psychology, 46(1), pp. 4-11, February.

McPhail, K. (2005). Care in the community: Profession ethics and the paradox of pro bono, Accounting Education, 14(2), pp. 213-227.

Meyer, J.E. (1993). New paradigm research in practice: the trials and tribulations of action research, Journal of Advanced Nursing, 18(7), pp. 1066-1072.

Montano, A.J., Cardoso, S. and Joyce, J. (2004). Skills development, motivation and learning in financial statement analysis: an evaluation of alternative types of case studies, Journal of Accounting Education, 13(2), pp.191-212.

Okafor, C.A. and Egbon, O. (2011). Academic Performance of Male versus Female Accounting Undergraduate Students: Evidence from Nigeria, Higher Education Studies, 1(1). 
Paisey, C. and Paisey, N.J. (2005). Improving accounting education through the use of action research, Journal of Accounting Education, 23(1), pp. 1-19.

Ramsden, P. (1983). The Lancaster Approaches to Studying and Course Perceptions Questionnaire: Lecturer's Handbook, Educational Methods Unit, Oxford Polytechnic. Ramsden, P. (1992). Learning to Teach in Higher Education, $3^{\text {rd }}$ Edition. London: Routledge. Reason, P. and McArdle, K.L. (2007). Brief notes on the theory and practice of action research. In Becker, S. and Bryman, A. (Eds) Understanding Research Methods for Social Policy and Practice, Centre for Action Research in Professional Practice, University of Bath.

Reissman, C. (1993). Narrative Analysis. London: Sage.

Saljo, R. (1979). Learning about learning, Higher Education, 8(4), pp. 443-451.

Samkin, G. and Francis, G. (2008). Introducing a Learning Portfolio in an Undergraduate Financial Accounting Course, Accounting Education: An International Journal, 179(3), pp. 233-271.

Sims, E. (2006). A New Shape for Schooling? Deep Learning 1: A New Shape for Schooling. London: Specialist Schools and Academics Trust.

Stanley, T. and Marsden, S. (2012). Problem-based learning: Does accounting education need it? Journal of Accounting Education, 30(3-4), pp. 267-289.

Schreier, M. (2012). Qualitative content analysis in practice. Thousand Oaks, CA: Sage.

Stout, D.E. and West, R.N. (2004). Using a stakeholder-based process to develop and implement an innovative graduate-level course in management accounting, Journal of Accounting Education, 22(9), pp. 95-118.

Tonge, R. and Willett, C. (2012). An Audit Learning Experience: A Pilot Project Through Cooperation with a Third Sector Organization, Accounting Education: An International Journal, 21(2), pp. 171-185.

Turner, M. and Baskerville, R. (2013). The Experience of Deep Learning by Accounting Students, Accounting Education: An International Journal, 22(6), pp. 582-604.

von Glasersfeld, E. (1995). Radical constructivism: A way of knowing and learning. London: Falmer Press.

von Glasersfeld, E. (1974). Piaget and the radical constructivist epistemology. In C. D. Smock \& E. von Glasersfeld (Eds.), Epistemology and education (pp. 1-24). Athens, GA: Follow Through Publications. Retrieved from http://www.vonglasersfeld.com/034

von Glasersfeld, E. (1989). Constructivism in education. In T. Husen \& T. N. Postlethwaite (Eds.), The international encyclopedia of education, supplement (Vol. 1, pp. 162 163). Oxford/New York: Pergamon Press.

von Glasersfeld, E. (2013). Radical Constructivism. Hoboken: Taylor and Francis.

Vygotsky, L.S. (1978). Mind in society: The development of higher psychological processes. Cambridge, MA: Harvard University Press. Originally published in Russian in 1930.

Watty, K., Jackson, M. and Yu, X. (2010). Students' Approaches to Assessment in Accounting Education: The Unique Student Perspective, Accounting Education: International Journal, 19(3), pp. 219-234.

Weber, R.P. (1990). Basic Content Analysis, $2^{\text {nd }}$ Edition. Newbury Park, CA: Sage Publications.

Wilkin, C.L. (2014). Enhancing the AIS curriculum: Integration of a research-led, problembased learning task, Journal of Accounting Education, 32(2), pp. 185-199.

Wilson, B.G. and Cole, P. (1991). A review of cognitive teaching models, Educational Technology Research \& Development, 39(4), pp. 47-63.

Yin. R. (2003). Case study research, $3^{\text {rd }}$ Edition. Thousand Oaks, CA: Sage. 
Qualitative Research in Accounting and Management

Page 34 of 42

$$
\begin{aligned}
& 1 \\
& 2 \\
& 3 \\
& 4 \\
& 5 \\
& 6 \\
& 7 \\
& 8 \\
& 9 \\
& 10 \\
& 11 \\
& 12 \\
& 13 \\
& 14 \\
& 15 \\
& 16 \\
& 17 \\
& 18 \\
& 19 \\
& 20 \\
& 21 \\
& 22 \\
& 23 \\
& 24 \\
& 25 \\
& 26 \\
& 27 \\
& 28 \\
& 29 \\
& 30 \\
& 31 \\
& 32 \\
& 33 \\
& 34 \\
& 35 \\
& 36 \\
& 37 \\
& 38 \\
& 39 \\
& 40 \\
& 41 \\
& 42 \\
& 43 \\
& 44 \\
& 45 \\
& 46 \\
& 47 \\
& 48 \\
& 49 \\
& 50 \\
& 51 \\
& 52 \\
& 53 \\
& 54 \\
& 55 \\
& 56 \\
& 57 \\
& 58 \\
& 59 \\
& 60
\end{aligned}
$$

3. 
Page 35 of 42

Qualitative Research in Accounting and Management

1

2

3

4

5

6

7

8

9

10

11

12

13

14

15

16

17

18

19

20

21

22

23

24

25

26

27

28

29

30

31

32

33

34

35

36

37

38

39

40

41

42

43

44

45

46

47

48

49

50

51

52

53

54

55

56

57

58

59

60
Table 1. Demographic profile of students on the course

\begin{tabular}{|l|l|}
\hline Key demographic factors & Statistics \\
\hline Nationality & Welsh $70 \%$ \\
& Chinese $15 \%$ \\
& English $10 \%$ \\
& Other 5\% \\
& Local (British) $80 \%$ \\
& International 20\% \\
\hline Age group & $20-21$ years $90 \%$ \\
& Above 21 years $10 \%$ \\
\hline Gender & Male 52\% \\
& Female 48\% \\
\hline
\end{tabular}

1 
Table 2. Connections between SOLO taxonomy and module and topic learning outcomes

\begin{tabular}{|c|c|}
\hline $\begin{array}{l}\text { Assignment's contribution to module and topic } \\
\text { learning outcomes }\end{array}$ & $\begin{array}{l}\text { OLO taxonomy levels and } \\
\text { ategories }\end{array}$ \\
\hline $\begin{array}{l}\text { Module learning outcomes: } \\
\text { 1. Describe decision-making models in practice. } \\
\text { 2. Discuss and analyse decision-making scenarios usi } \\
\text { appropriate accounting techniques. } \\
\text { 3. Discuss and evaluate the limitations of accounti } \\
\text { techniques. } \\
\text { 4. Critically evaluate and reflect on behavioural aspec } \\
\text { of management accounting (including its role } \\
\text { organisations and society). }\end{array}$ & $\begin{array}{l}\text { One relevant aspect (uni- } \\
\text { structural) competence. } \\
\text { Integrate several relevant } \\
\text { aspects into one structure } \\
\text { (multi-structural and relational } \\
\text { competence). } \\
\text { Integrate several relevant } \\
\text { aspects into one structure } \\
\text { (multi-structural and relational } \\
\text { competence). } \\
\text { Integrate several aspects and } \\
\text { theoretically understand a new } \\
\text { domain (relational and extended } \\
\text { abstract competence). }\end{array}$ \\
\hline $\begin{array}{l}\text { 3. Identify incremental costs. } \\
\text { 4. Analyse and categorise decision-making pra }\end{array}$ & $\begin{array}{l}\text { One relevant aspect (uni- } \\
\text { structural competence). } \\
\text { Integrate several relevant } \\
\text { aspects into one structure } \\
\text { (multi-structural and relational } \\
\text { competence). } \\
\text { One relevant aspect (uni- } \\
\text { structural) competence. } \\
\text { Integrate several relevant } \\
\text { aspects into one structure } \\
\text { (multi-structural and relational } \\
\text { competence). } \\
\text { Integrate several aspects and } \\
\text { theoretically understand a new } \\
\text { domain (relational and extended } \\
\text { abstract competence). }\end{array}$ \\
\hline
\end{tabular}

Source: Adapted from Biggs and Collis (1982) and Biggs and Tang (2007) 


\section{Table 3. SOLO taxonomy and learning tasks}

\begin{tabular}{|l|l|}
\hline Level of thinking and learning & Learning tasks \\
\hline Pre-structural & $\begin{array}{l}\text { Participation in mini-class activities to understand } \\
\text { financial decision environment. }\end{array}$ \\
\hline Uni-structural & $\begin{array}{l}\text { Participation in mini-class activities to familiarise } \\
\text { themselves with the bounded rational model of decision } \\
\text { making. }\end{array}$ \\
\hline Multi-structural & $\begin{array}{l}\text { Participation in mini-class activities to familiarise } \\
\text { themselves with various decision-making models as a } \\
\text { whole and understand the relevant costing assumptions } \\
\text { and criteria that create the information that facilitates the } \\
\text { decisions. }\end{array}$ \\
\hline Relational & $\begin{array}{l}\text { In-depth interviews with } 6 \text { to } 8 \text { people, identifying any } \\
\text { major financial decisions they have made in the recent } \\
\text { past. Applying the decision-making models and relevant } \\
\text { cost techniques and analysing the decision-making } \\
\text { process. }\end{array}$ \\
\hline Extended abstract \\
$\begin{array}{l}\text { decision makers' criteria and accounting language, and } \\
\text { theoretically generalising study findings. }\end{array}$ \\
\hline
\end{tabular}

Source: Adapted from Biggs and Collis (1982) and Biggs and Tang (2007) 
Table 4. Levels of SOLO taxonomy and inter-rater agreements for coursework marking

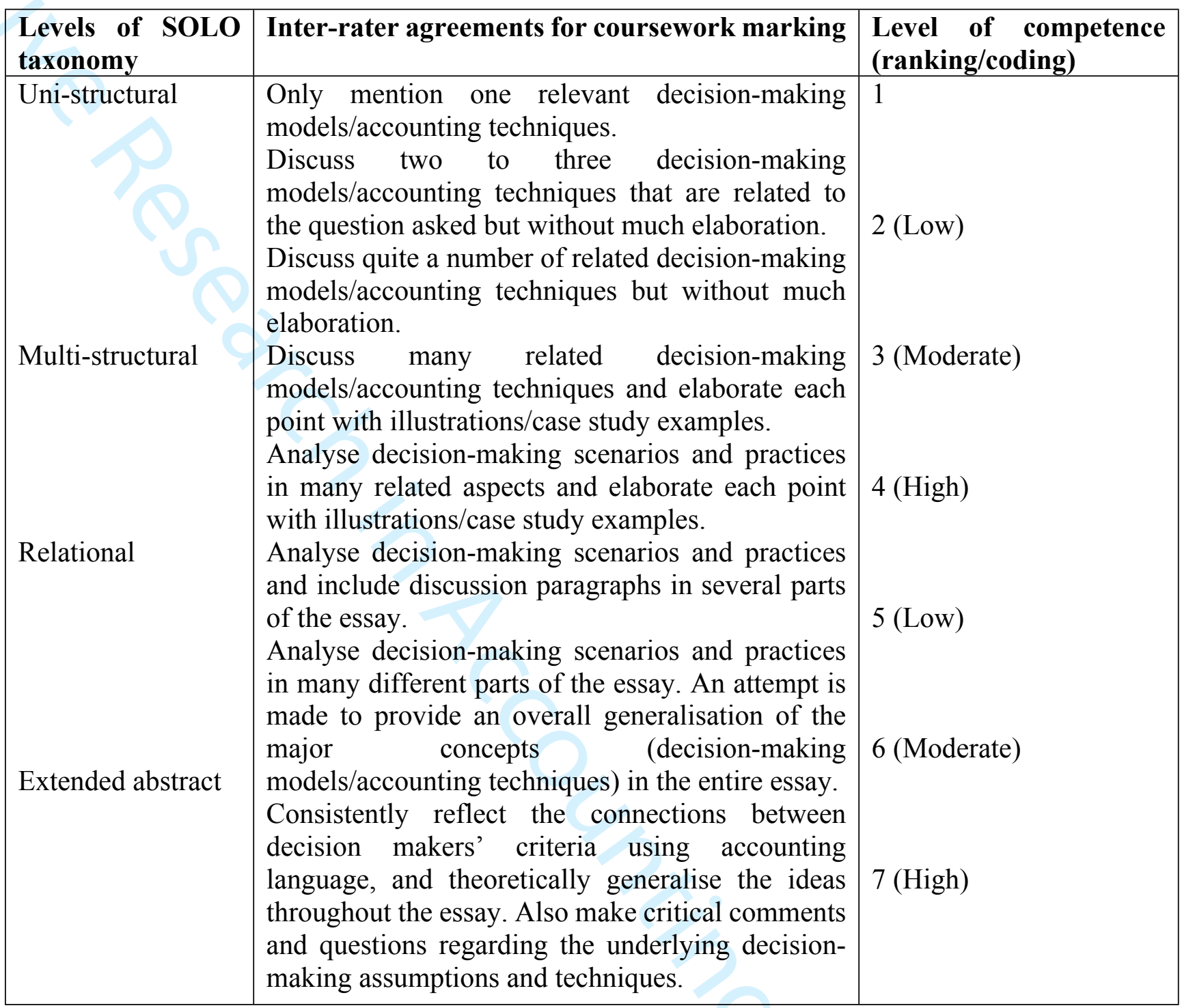

Source: Adapted from Biggs and Collis (1982) and Biggs and Tang (2007) 


\section{Table 5. Allocation of marks}

\begin{tabular}{|l|c|}
\hline Key areas & $\begin{array}{c}\text { Marks } \\
\mathbf{( 1 0 0 \% )}\end{array}$ \\
\hline $\begin{array}{l}\text { Introduction and theory } \\
\text { Methodology (including }\end{array}$ & $35 \%$ \\
$\begin{array}{l}\text { structure and presentation) } \\
\text { Discussion and analysis } \\
\text { (overall structure and } \\
\text { style) }\end{array}$ & $45 \%$ \\
\begin{tabular}{l} 
Evaluation and conclusion \\
\hline
\end{tabular} & $10 \%$ \\
\hline
\end{tabular}


Qualitative Research in Accounting and Management

Page 40 of 42

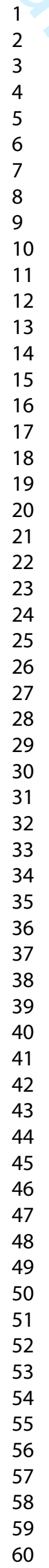

Table 6. Analysis of marks (Coursework and Final exam)

\begin{tabular}{|l|l|c|c|c|}
\hline Class & Range & Coursework (30\%) & Final Exam (70\%) & Total (100\%) \\
\hline First class & $70 \%$ and over & $4(7 \%)$ & $8(14.2 \%)$ & $6(10.71)$ \\
Upper second & $60 \%-69 \%$ & $6(11 \%)$ & $15(26.7 \%)$ & $13(23.21 \%)$ \\
Lower second & $50 \%-59 \%$ & $25(44 \%)$ & $12(21.42 \%)$ & $16(28.57 \%)$ \\
Pass & $40 \%-49 \%$ & $19(34 \%)$ & $15(26.78 \%)$ & $16(28.57 \%)$ \\
Fail & Below 40\% & $2(4 \%)$ & $6(10.71 \%)$ & $5(8.9 \%)$ \\
\hline Total & & 56 & 56 & 56 \\
\hline
\end{tabular}




\section{Figure 1. Mini-group activities promoted during lectures}

\section{Quick Quiz 1}

- Think of a decision you have made recently that involved some financial implications.

- Think about a decision that involved society/community, and had some financial implications.

\section{Quick Quiz 2}

- Think about a situation in your personal life where you followed a rational model to make your decision. Explain the steps and criteria you followed.

- Think about a situation in your personal life where you followed a bounded rational model to make your decision. Explain the criteria you adopted.

\section{Quick Quiz 3}

- Think about an everyday-life situation in which you applied the incremental cost method in your decision making. Discuss in groups: Which model did you follow? What relevant/irrelevant costs were considered? Any opportunity cost? Qualitative factors? 
Figure 2. Detailed guidelines on assignment purpose and methodology

- You are required to pick between 6 and 8 people for the study. You are advised to choose decision-making situations that generally interest you (e.g. buying/renting a new house/car, going on holiday, buying household items, changing careers, etc.).

- However, the condition is that the situation should be recent and should have involved a major financial decision.

- You might have to think more creatively and critically about the application of theories to the decisions in question.

- You may want to do a bit of exploratory research on whether the selected people considered two or three options before making the final decision.

- Make sure you have enough data from the interviews to complete the project. To do this, prepare your own questions and general guidelines for the interviews. You might focus on

- the decision maker's background (Who?)

- the decision-making objectives (What? and Why?)

- steps and criteria used for decision making (How?)

- who else was involved/consulted? (Why?)

- incremental costs and other information concerned with the decisions (the calculative practice)

- how did they make the final decision? (Why?)

- qualitative factors involved in the decision analysis.

- Make notes while interviewing (if possible, tape record).

- Based on these notes, write down the individual stories of each interviewee (the cases) and attach them in an appendix. 